\title{
Spatial structure on moderately exposed rocky shores: patch scales and the interactions between limpets and algae
}

\author{
Mark P. Johnson ${ }^{1, *}$, Michael T. Burrows ${ }^{2}$, Richard G. Hartnoll ${ }^{3}$, Stephen J. Hawkins ${ }^{1}$ \\ 'School of Biological Sciences, Division of Biodiversity and Ecology, University of Southampton, Southampton SO16 7PX, \\ United Kingdom \\ ${ }^{2}$ Dunstafínage Marine Laboratory, PO Box 3, Oban, Argyll PA34 4AD, United Kingdom \\ ${ }^{3}$ Port Erin Marine Laboratory, Port Erin, Isle of Man IM9 6JA, United Kingdom
}

\begin{abstract}
The spatial pattern of limpet grazing has been previously hypothesised to drive a mosalc of algal patches on moderately exposed shores in the northeast Atlantic. The presence of differently aged algal patches and spatial effects associated with limpets were tested for using spatially referenced data sets. Algal and limpet occurrences in $0.01 \mathrm{~m}^{2}$ cells were recorded in a series of $25 \mathrm{~m}^{2}$ quadrats on shores on the Isle of Man. All sites showed small-scale spatial autocorrelation for limpets and mature and juvenile algae. Hence the sites surveyed had an uneven distribution of limpets superimposed on a mosaic of differently aged patches of algae. The local density of limpets was related to the probability of a cell containing juvenile algae in 7 of the 10 quadrats surveyed. Where they had an effect, limpets generally reduced the probability of juvenile algae being recorded locally, as would be predicted by the grazer-driven mosaic hypothesis.
\end{abstract}

KEY WORDS: Limpets · Algae - Spatial statistics Mosaic · Grazing

\section{INTRODUCTION}

Understanding the generation of pattern across different scales can be considered as the central problem in ecology (Levin 1992). On rocky shores, pattern is often discussed in terms of patchiness, where patches are generated by spatial variation in processes such as physical disturbance (Paine \& Levin 1981, Sousa 1985), settlement and recruitment (Caffey 1985, Vadas et al. 1992), grazing (Hawkins \& Hartnoll 1983a, Jernakoff 1983), and predation (Fairweather 1988). Given the presence of spatial pattern, it is ironic that welldesigned field experiments must seek to avoid any small-scale spatial dependencies between replicates (Cressie 1993, Underwood 1997). If experiments are to be used as models of ecosystem function, some definition of the scales at which patch generating processes

•E-mail:m.p.johnson@soton.ac.uk operate is necessary. Statistics which summarise the dependencies in spatially referenced data sets are valuable in this context (Rossi et al. 1992). The use of spatial statistics clarifies decisions about the appropriate size of plots for experimentation or monitoring (Underwood \& Chapman 1996). Certain hypotheses and tests only arise when spatially referenced data sets are considered (Thomson et al. 1996)

This study focuses on spatial aspects of rocky shore communities on the Isle of Man, in particular the algal mosaic (dominated by canopy-forming Fucus spp.) on the moderately exposed ledges at Port St. Mary (Jones 1948, Lodge 1948, Burrows \& Lodge 1950, Southward 1956, 1964, Hartnoll \& Hawkins 1980, Hawkins 1981a, b, 1983, Hawkins \& Hartnoll 1983b). Time series records from a $2 \times 1 \mathrm{~m}$ fixed quadrat at Port St. Mary show fluctuations between periods of high and low algal cover (Hartnoll \& Hawkins 1985). This pattern has been interpreted, in the light of the previously 
cited work, as the growth and decay of patches generated by biological interactions (Hartnoll \& Hawkins 1985, Hawkins et al. 1992). Limpets (Patella spp.) are the dominant grazers in the system and their home scars tend to be aggregated with a preference for mature algal patches. Individual limpets forage for short distances during tidal submersion before returning to the home scar during emersion (Hartnoll \& Wright 1977). Therefore, the locations of home scars on a shore indicate the spatial pattern of grazing. A spatially uneven pattern of grazing pressure is proposed to lead to new algal patches in areas of low local limpet density (Hartnoll \& Hawkins 1985). In mature algal patches, new individuals are not recruited due to interference from limpets, so patches eventually disappear as adult plants are lost. The hypothesis outlined above can explain the 6 to $7 \mathrm{yr}$ cycles in the abundance of fucoids and limpets observed at single sites on moderately exposed rocky shores. However, Chapman (1995) cautioned that many of the original experiments were not replicated, and that a 'just so' story may have been fitted to insufficient evidence.

A variety of processes acting at different scales could be responsible for the temporal fluctuations in algal cover observed at a single site. The simplest hypothesis is that algal recruitment varies from year to year. If this is the case there would be no coherent spatial segregation of juvenile and mature algae. Alternatively there may be spatial and temporal variation in algal recruitment. The spatial variation may or may not be linked to the local limpet density.

In this paper we use data from a series of $25 \mathrm{~m}^{2}$ quadrats to discriminate between the alternative algal recruitment hypotheses of temporal variation, spatiotemporal variation and spatiotemporal variation linked to the local limpet density. Data were recorded in $0.01 \mathrm{~m}^{2}$ grid cells, a spatial scale relevant to the foraging excursions of limpets $(0.4 \mathrm{~m}$; Hartnoll \& Wright 1977). The relative time of a cell's most recent algal colonisation was estimated by classifying algae-occupied cells as juvenile or mature. Patterns of cell occupancy were examined using spatial autocorrelation. Logistic regressions based on the limpet numbers recorded in each cell were used to test for spatial relationships between grazers and the occurrence of juvenile algae. The predictions of the competing algal recruitment hypotheses are: (1) if the observed temporal fluctuations are due to algal recruitment varying from year to year, but with no spatial pattern, there will be no spatial autocorrelation of mature and juvenile algal cells; (2) spatial and temporal variation in recruitment will lead to autocorrelation of mature and juvenile algal cells; (3) if spatiotemporal patchiness is generated by grazing, the local density of limpets will affect the probability of recording a cell occupied by juvenile algae

\section{MATERIALS AND METHODS}

Field data. A series of ten $25 \mathrm{~m}^{2}$ quadrat surveys were made in the mid intertidal zone of 4 shores on the Isle of Man: Poyll Vaaish (U.K. Ordinance Survey grid reference: SC 239 682), Gansey (SC 215 680), Port St. Mary (SC 212 669) and Derbyhaven (SC 295 686). Four quadrats were marked out at Port St. Mary, separated by distances of at least $50 \mathrm{~m}$. All the sites were level or gently sloping with no large cracks or boulders. These sources of local topographic variation were avoided as the hypothesis being tested refers to relatively level shores. The bedrock at Port St. Mary and Poyll Vaaish was smooth carboniferous limestone. In comparison, the quadrat at Gansey was marked out across an area of uneven slate. Small ridges of slate up to approximately $0.1 \mathrm{~m}$ in height gave the surface at Gansey a jagged appearance. The Derbyhaven site was on a concrete slab which forms part of the base of a gantry built for Ronaldsway airport.

Sites were surveyed either during spring or autumn 1996, with repeat surveys in spring 1997 at Gansey and 2 locations at Port St. Mary. A $0.5 \times 0.5 \mathrm{~m}$ quadrat divided into 25 squares was progressively moved through each site to produce a map of $50 \times 50$ cells. Each $0.01 \mathrm{~m}^{2}$ cell was coded for the presence or absence of algae. If algae were present, cells were divided further into 'mature' or 'juvenile' categories, a juvenile cell being one where juvenile algae were found in a cell without mature algae. Juveniles were distinguished from mature algae by frond lengths less than $0.1 \mathrm{~m}$ (Knight \& Parke 1953) and the lack of reproductive structures. Mature Fucus individuals can grow up to approximately $0.6 \mathrm{~m}$ long (Knight \& Parke 1953) The number of adult limpets (shell diameter $>15 \mathrm{~mm}$ ) in each $0.01 \mathrm{~m}^{2}$ cell was also recorded. Limpets less than $15 \mathrm{~mm}$ in diameter were generally infrequent and are not considered further in the analysis presented here.

Data analysis. To characterise spatial autocorrelation at the different sites, the number of times that pairs of cells were recorded in the same state was used (join counts; Upton \& Fingleton 1985). The neighbourhood for each cell included all orthogonal and diagonal connections at a specific distance. This is known as the queen's definition of contiguity, by analogy with chess moves (Sokal \& Oden 1978). If limpet or algal patches exist at a scale above $0.01 \mathrm{~m}^{2}$ there will be positive spatial autocorrelation and higher than expected numbers of joins between cells. Comparing the degree of autocorrelation over successively greater distances can give an estimate of the average size of patches. When the distance between cells being compared exceeds the patch size, the number of joins will fall to a background level. Deviations from the average level of join 
counts in the absence of spatial autocorrelation can be

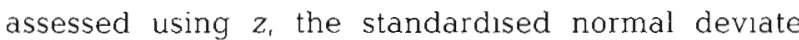
(Sokal \& Oden 1978, Upton \& Fingleton 1985). The expected number of joins and the variance of this value were calculated using the equations presented in Upton \& Fingleton (1985). The valıdıty of using a normal approximation was confirmed using randomly generated $50 \times 50$ cell matrices. Join counts were compared with expected at 25 distances from the occupled cell. This involved a degree of multıple hypothesis testing, so the significance criterion for results was adjusted to reduce the chances of Type 1 error Observed join counts were taken to be significantly more common than that expected in the absence of spatial autocorrelation only if $z$ scores exceeded 3.0902 (a critical value of $5 \%, 2$-tailed, in 25 tests) The magnitude of individual $z$ scores can also be interpreted as a measure of how well-defined patches are

An important part of the Hartnoll \& Hawkins (1985) mosaic model is that aggregated limpets leave spaces between the clumps where Fucus escapes are more likely. This hypothesis was tested by examining the fits of a logistic regression (Sokal \& Rohlf 1995) to the data. The fitted equation estimates the odds of an escape occurring as a function of the local limpet density

$$
\ln \left(\frac{P_{\text {escape }}}{1-P_{\text {escape }}}\right)=\beta_{0}+\beta_{1} L_{0}+\beta_{2} L_{1}+\ldots+\beta_{N+1} L_{N}
$$

where $L_{0}$ is the number of limpets in the current cell. $L_{N}$ is the total number of limpets in all cells at a distance $N$ from the current cell, and $\beta_{0}$ to $\beta_{N+1}$ are fitted parameters. Eq. (1) was fitted to data sets with increasing numbers of independent varuables to the point where adding another distance class for limpets ceased to significantly improve the fit to data. This test for the improvement in fit with each addition of a new independent variable involved taking the difference between the log likelihood values multiplied by -2 for each model. An improvement in fit was accepted if the difference in $-2 \times \log$ likelihoods exceeded the critıcal value of chi-squared with 1 degree of freedom. The statistically fitted models were only accepted if their overall 'goodness of fit' (sum of normalised squared residuals) did not exceed chi-squared at the $5 \%$ level (Norusis/SPSS Inc 1993).

\section{RESULTS}

Algal cover and the relative proportions of cells classified as mature or juvenile varied between quadrats (Fig. 1). Changes between successive surveys of the same quadrat imply that the patterns recorded are dynamic at an annual scale. Up to $80 \%$ of cells initially classified as juvenile were recorded as mature by the

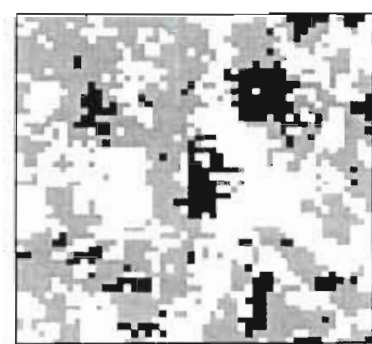

PSM al

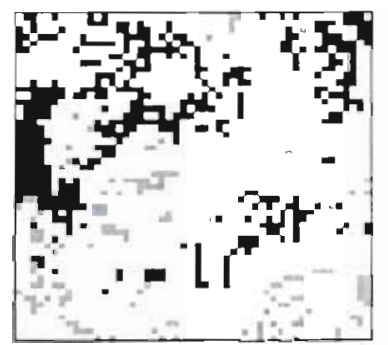

PSM bl

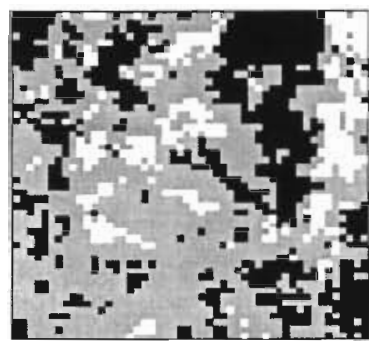

PSM $c$

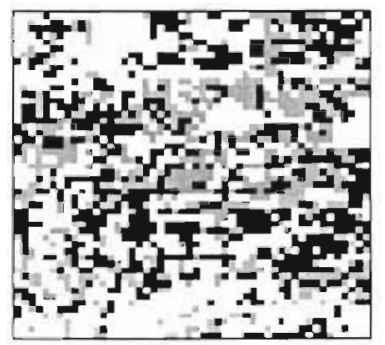

Gansey 1

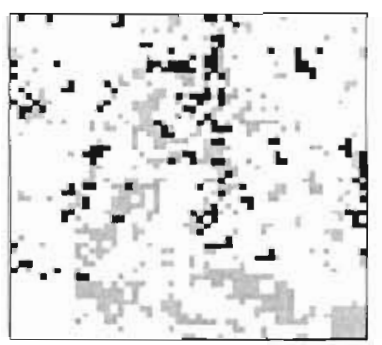

Poyll Vaaish

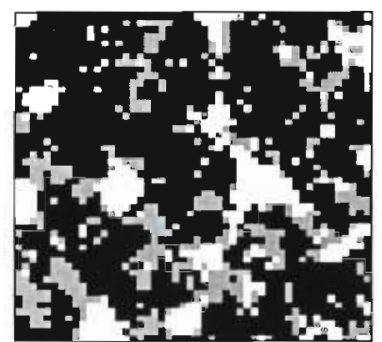

PSM a2

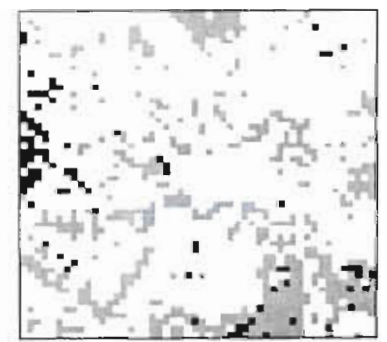

PSM b2

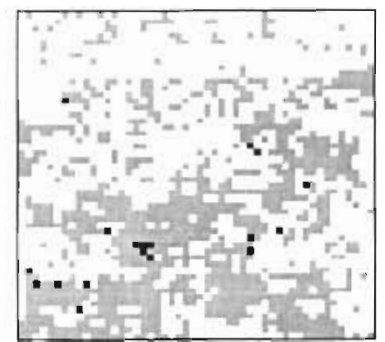

PSM d

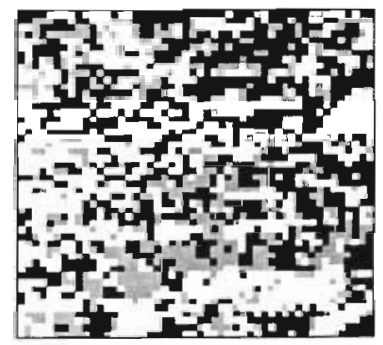

Gansey 2

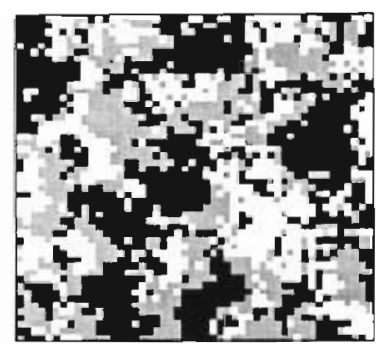

Derbyhaven
Fig. 1 Spatial variation of algal cover in the quadrats surveyed. Black cells. mature algae, grey cells: only juvenile algae, white cells no algae PSM a, b, c, and d. separate sites of quadrats at Port St Mary PSM a, PSM b and Gansey were surveyed in both 1996 and 1997 


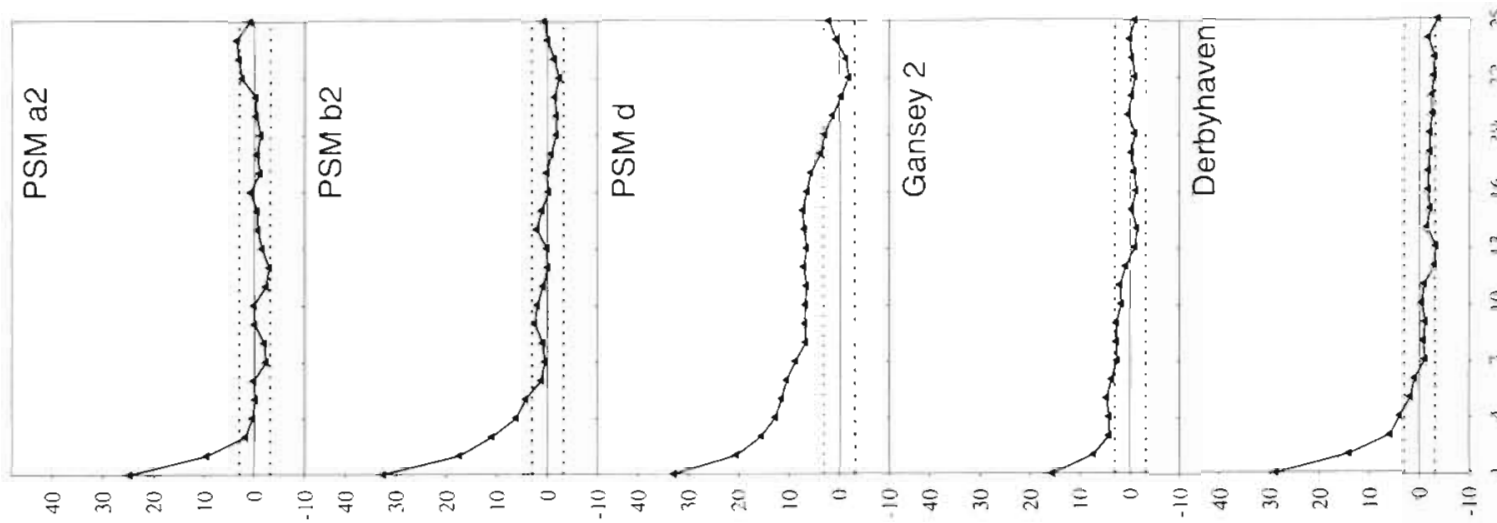

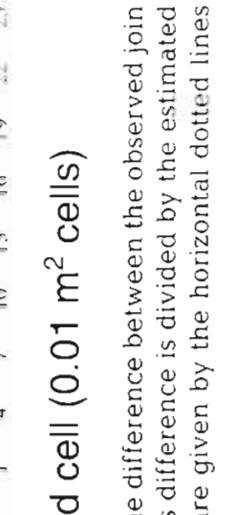

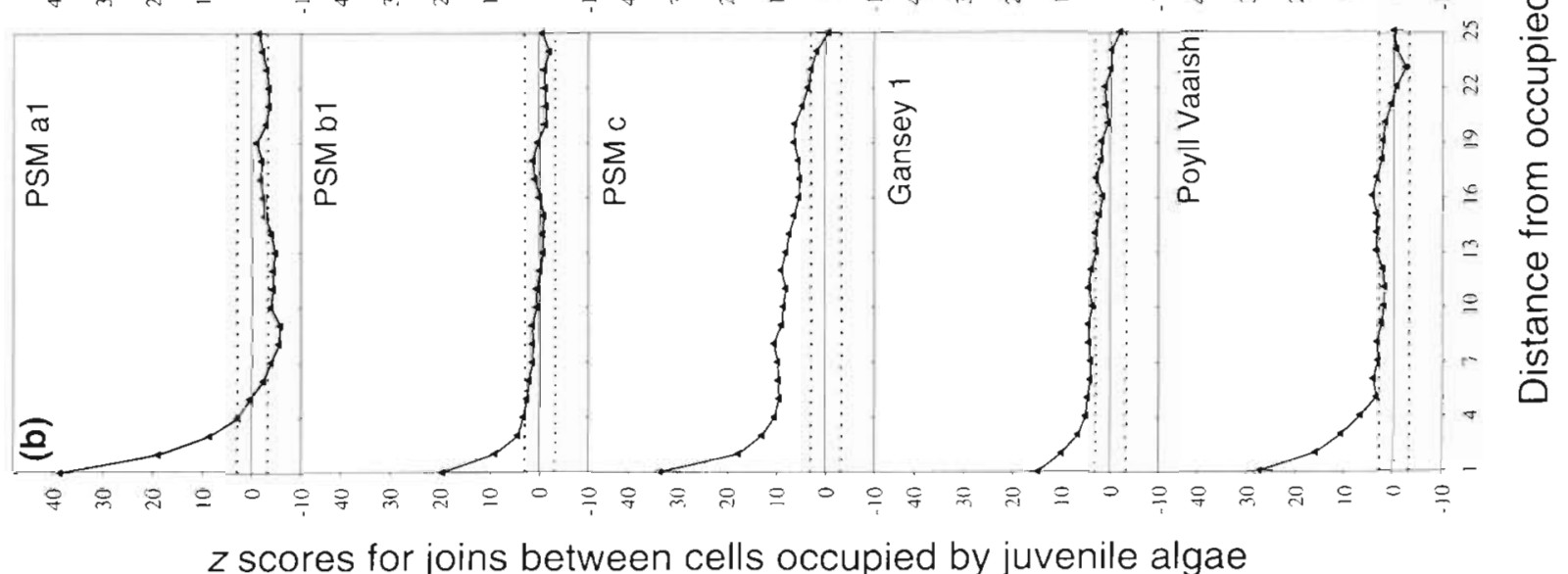

$\Xi \stackrel{\infty}{\nexists}$

E

웜

菏

점

0.

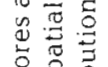

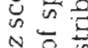

is 8

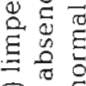

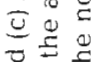

$\underset{\sigma}{\Xi}$

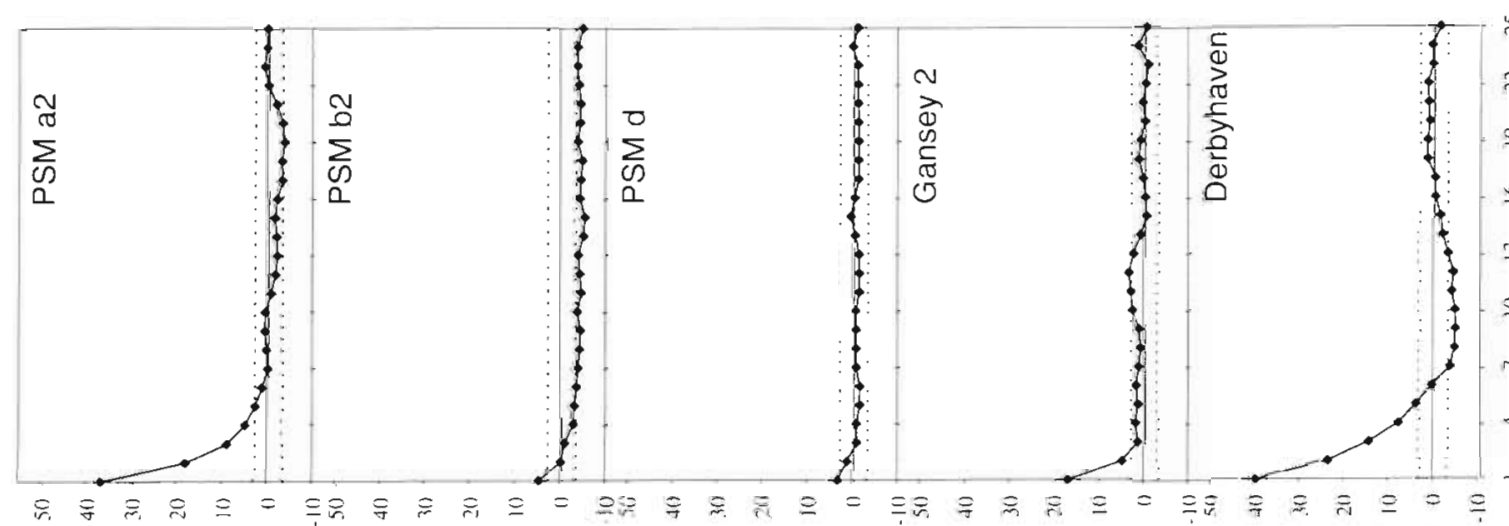

$\because \mathscr{G}$

흐을 궁

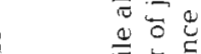

政

$=\frac{0}{\overline{0}} \underline{\underline{\theta}}$

$=0$ 过

- $\frac{\sigma}{\sigma} \frac{0}{0} \frac{0}{0}$

- $E$ d

○

요 $\stackrel{0}{\circ}$

$\overline{\overline{0}} \overline{0} \overline{0} \frac{\pi}{0}$

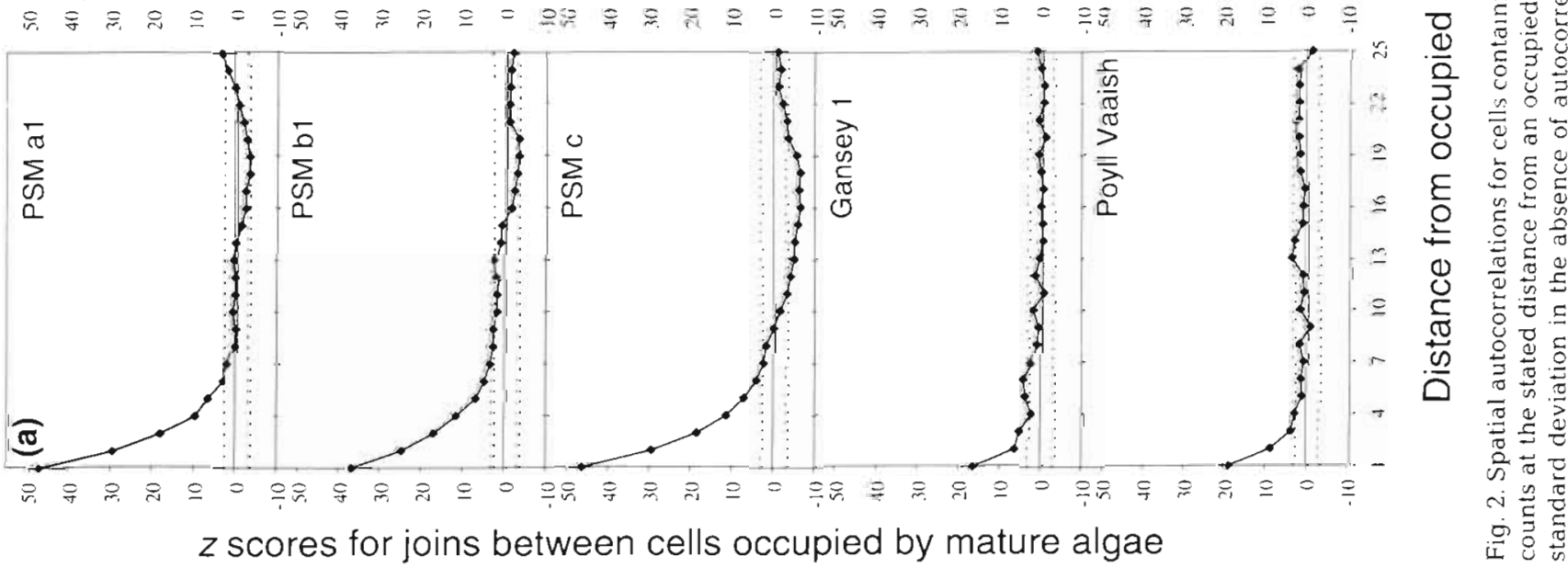




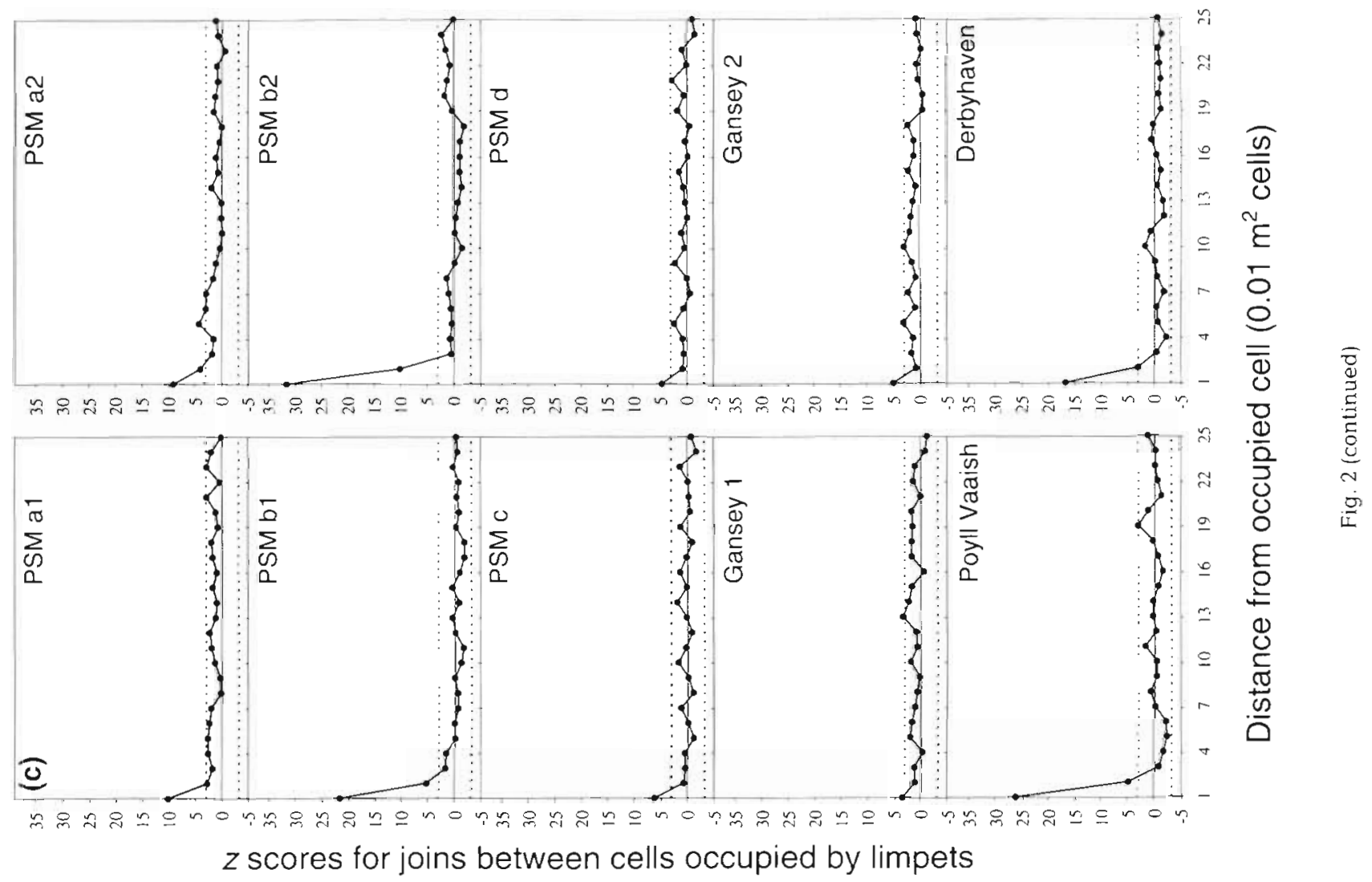

time of the second survey (Port St. Mary a 1 to Port St. Mary a2).

Join count statistics for cells occupied by limpets or mature or juvenile algae all showed significant spatial autocorrelation at the scale measured (Fig. 2). The tendency of all curves to stay within the confidence intervals at distances approaching $2.5 \mathrm{~m}$ suggests that there were few larger patterns evident in the $5 \times 5 \mathrm{~m}$ quadrats, such as down shore gradients or regular spacing of patches. Limpet occurrences were autocorrelated over 1 or 2 cells whereas algal patch scales were more variable. The density of adult limpets recorded in surveys ranged from 8.04 to $38.36 \mathrm{~m}^{-2}$, with the highest densities recorded in the Gansey quadrat. A maximum of 7 limpets were recorded in a single $0.01 \mathrm{~m}^{2}$ cell.

The local density of limpets was estimated to affect the probability of juvenile algal cells being recorded in 7 of the 10 quadrats (Table 1). Limpets affected the chance of encountering juvenile algae at ranges up to 4 cells, depending on the site. The impact that a unit change in limpet number has on the odds of an escape can be seen by examining the effects of multiplication by the values in the column for $\exp (\beta)$. In all but 1 case (Port St. Mary b2), increasing the local density of limpets reduced the odds of finding juvenile algae. However, the standard error for the positive estimate of $\beta$ is fairly large so the difference from a negative value may not be significant. The effect of limpets on the probability of a cell containing juvenile algae generally decreased with increasing distance class.

\section{DISCUSSION}

The analysis of spatially referenced data sets demonstrated patch structures of limpets and algae at all sites with scales between 0.1 and $2 \mathrm{~m}$. The distinct autocorrelations of cells classed as mature or juvenile algae indicate that algal recruitment varied in space as well as time. Local limpet density was related to the probability of a cell containing juvenile algae in 7 of the 10 surveys. Where they had an impact, limpets generally reduced the probability of local algal recruitment.

The results support the hypothesis (Hartnoll \& Hawkins 1985) of a role for limpet grazers in the generation of algal patch structure on moderately exposed rocky shores. However, the generality of such a grazer-driven mosaic is unclear. Limpets had an impact at some sites but not all. The proportion of 
Table 1. Logistic regressions for the odds of a cell containing juvenile algae dependent on the sum of limpet numbers in $0.01 \mathrm{~m}^{2}$ cells at different distances from the current cell (see Eq. 1 in text). The goodness of fit (sum of normalised squared residuals) is compared to chi-squared, with degrees of freedom dependent on the number of parameters fitted in the model. If the residuals from the fitted model are large the goodness of fit will exceed the critical value of chi-squared. ns: not signifrant at the $5 \%$ level

\begin{tabular}{|c|c|c|c|c|c|c|c|c|c|c|}
\hline \multirow[t]{2}{*}{ Site } & & \multirow[t]{2}{*}{ Constant } & \multicolumn{5}{|c|}{ Limpet distance class from current cell } & \multirow{2}{*}{$\begin{array}{l}\text { Goodness } \\
\text { of fit }\end{array}$} & \multirow[t]{2}{*}{$\mathrm{df}$} & \multirow[t]{2}{*}{$p$} \\
\hline & & & 0 & 1 & 2 & 3 & 4 & & & \\
\hline \multirow[t]{3}{*}{ PSM a 1} & $\beta$ & 0.7336 & -0.5386 & -0.1926 & -0.1687 & -0.1010 & -0.0532 & & & \\
\hline & SE of $\beta$ & 0.1733 & 0.1929 & 0.0512 & 0.0449 & 0.0368 & 0.0226 & & & \\
\hline & $\operatorname{Exp}(\beta)$ & 2.0826 & 0.5836 & 0.8248 & 0.8448 & 0.9039 & 0.9482 & 888.315 & 894 & ns \\
\hline \multirow[t]{3}{*}{ PSM b1 } & $\beta$ & -2.4107 & -0.6138 & -0.1284 & -0.3537 & -0.2386 & & & & \\
\hline & SE of $\beta$ & 0.8850 & 0.1950 & 0.1997 & 0.1325 & 0.1983 & & & & \\
\hline & $\operatorname{Exp}(\beta)$ & 0.0898 & 0.5413 & 0.8795 & 0.7021 & 0.7877 & & 750.606 & 895 & ns \\
\hline \multirow[t]{3}{*}{ PSM b2 } & $\beta$ & -1.1552 & 0.2592 & -0.4624 & & & & & & \\
\hline & SE of $\beta$ & 0.0879 & 0.3186 & 0.1148 & & & & & & \\
\hline & $\operatorname{Exp}(\beta)$ & 0.3150 & 1.2959 & 0.6298 & & & & 931.240 & 897 & ns \\
\hline \multirow[t]{3}{*}{ PSM C } & $\beta$ & 0.6099 & -0.4504 & -0.1312 & & & & & & \\
\hline & SE of $\beta$ & 0.0816 & 0.2201 & 0.0656 & & & & & & \\
\hline & $\operatorname{Exp}(\beta)$ & 1.8402 & 0.6374 & 0.8771 & & & & 899.626 & 897 & ns \\
\hline \multirow[t]{3}{*}{ PSM d } & $\beta$ & 0.8376 & -0.8407 & -0.2819 & -0.1696 & -0.0952 & & & & \\
\hline & SE of $\beta$ & 0.1624 & 0.1966 & 0.0581 & 0.0490 & 0.0419 & & & & \\
\hline & $\operatorname{Exp}(\beta)$ & 2.3108 & 0.4314 & 0.7543 & 0.8440 & 0.9092 & & 904.552 & 895 & ns \\
\hline \multirow[t]{3}{*}{ Gansey 2} & $\beta$ & -0.6088 & -0.2050 & -0.1397 & & & & & & \\
\hline & SE of $\beta$ & 0.1517 & 0.1176 & 0.0397 & & & & & & \\
\hline & $\operatorname{Exp}(\beta)$ & 0.5440 & 0.8146 & 0.8696 & & & & 899.814 & 897 & $\mathrm{~ns}$ \\
\hline \multirow[t]{3}{*}{ Derbyhaven } & $\beta$ & -0.3477 & -1.2910 & -0.2433 & & & & & & \\
\hline & $\mathrm{SE}$ of $\beta$ & 0.0813 & 0.3867 & 0.0610 & & & & & & \\
\hline & $\operatorname{Exp}(\beta)$ & 0.7063 & 0.2750 & 0.7841 & & & & 884.806 & 897 & ns \\
\hline
\end{tabular}

limpets remaining faithful to a single home scar over the course of a year would certainly affect the spatial relationships with juvenile algae. The effect of limpets also varied in presence and extent from year to year at the same site. One potential reason for the absence of any detected limpet effect is that grazers may have been 'swamped' by an exceptionally good algal recruitment. This may have happened between the 2 surveys at Port St. Mary a, where $65 \%$ of cells not originally occupied by algae contained algae on the second survey.

It is not clear what site-specific factors could have been responsible for the differences between quadrats in the extent and degree of limpet effects on juvenile algal occurrence. Surface roughness may interfere with the grazing of limpets, reducing their local effects on algal recruitment probabilities (cf. Lubchenco 1983). The surface roughness of quadrats in this study was crudely estimated using the ratio of a length of a tape stretched out across a quadrat to the length of the same line after the tape had been pressed into surface irregularities. The average of 5 such ratios was used for each quadrat. This estimate of surface irregularity confirmed Gansey as the roughest site. Autocorrelations and limpet impacts at Gansey were generally amongst the weakest found. However, rank correlations of quadrat surface rough- ness with limpet grazing effects did not show any significant trends.

Statistics which examine the spatial dependencies in ecosystems represent methods of expanding and testing hypotheses which complement, but do not replace, more traditional experimental approaches. The additional information available from spatially referenced data sets are of interest in their own right. This study reinforces the view of considerable small-scale patchiness linked to the behaviour patterns of intertidal organisms (Underwood \& Chapman 1996). Further work is required to distinguish between the roles of limpet grazing and other potential causes of algal patchiness such as microhabitat heterogeneity, other grazers, algae-algae interactions and algae-barnacle interactions

Acknowledgements. This research was funded by a grant in the NERC special topic: 'Testable models of aquatic ecosystems' We thank Prof. R. N. Hughes and P. C. Watts for comments on an earlier draft of this manuscript. Simon Bray assisted with fieldwork in the autumn survey.

\section{LITERATURE CITED}

Burrows EM, Lodge SM (1950) Note on the inter-relationships of Patella, Balanus and Fucus on a semi exposed coast. Annu Rep Mar Biol Stat Port Erin 62:30-34 
Caffey HM (1985) Spatial and temporal variation in settlement and recruitment of intertidal barnacles. Ecol Monogr 55:313-332

Chapman ARO (1995) Functional ecology of fucoid algae twenty-three years of progress. Phycologia 34:1-32

Cressie NAC (1993) Statistics for spatial data. John Wiley \& Sons Inc, New York

Fairweather PG (1988) Predation creates haloes of bare space among prey on rocky seashores in New South Wales. Aust J Ecol 13:401-409

Hartnoll RG, Hawkins SJ (1980) Monitoring rocky shore communities: a critical look at spatial and temporal variation. Helgolànder Meeresunters 33:484-495

Hartnoll RG, Hawkins SJ (1985) Patchiness and fluctuations on moderately exposed rocky shores. Ophelia 24:53-63

Hartnoll RG, Wright JR (1977) Foraging movements and homing in the limpet Patella vulgata L. Anim Behav 25 $806-810$

Hawkins SJ (1981a) The influence of season and barnacles on algal colonisation of Patella vulgata L exclusion areas J Mar Biol Assoc UK 61:1-15

Hawkins SJ (1981b) The influence of Patella grazing on the fucoid/barnacle mosaic on moderately exposed rocky shores. Kieler Meeresforsch 5:537-544

Hawkins SJ (1983) Interaction of Patella and macroalgae with settling Semibalanus balanoides (L.). J Exp Mar Biol Ecol 71:55-72

Hawkins SJ, Hartnoll RG (1983a) Grazing of intertidal algae by marine invertebrates. Oceanogr Mar Biol Annu Rev 21. $195-282$

Hawkins SJ, Hartnoll RG (1983b) Changes in a rocky shore community: an evaluation of monitoring. Mar Environ Res 9:131-181

Hawkins SJ, Hartnoll RG, Kain(Jones) JM, Norton TA (1992) Plant-animal interactions on hard substrata in the north-east Atlantic. In: John DM, Hawkins SJ, Price JH (eds) Plant-animal interactions in the marine benthos. Systematics Association Spec Vol 46. Clarendon Press, Oxford, p 1-32

Jernakoff $\mathrm{P}$ (1983) Factors affecting the recruitment of algae in a midshore region dominated by barnacles. J Exp Mar Biol Ecol 67:17-31

Jones NS (1948) Observations and experiments on the biology of Patella vulgata at Port St. Mary, Isle of Man. Proc Trans Liv Biol Soc 56:60-77

Knight M, Parke M (1953) A biological study of Fucus vesicu-

Editorial responsibility: Otto Kinne (Editor)

Oldendorf/Luhe, Germany losus L. and F. serratus L. J Mar Biol Assoc UK 29:439-514 Levin SA (1992) The problem of pattern and scale in ecology. Ecology 73:1943-1967

Lodge SM (1948) Algal growth in the absence of Patella on an experimental strip of foreshore, Port St. Mary, Isle of Man. Proc Trans Liv Biol Soc 56:78-83

Lubchenco J (1983) Littorina and Fucus: effects of herbivores, substratum heterogeneity, and plant escapes during sucession. Ecology 62:1116-1123

Norusis MJ/SPSS Inc (1993) SPSS for windows: advanced statistics release 6.0. SPSS Inc, Chicago

Paine RT, Levin SA (1981) Intertidal landscapes: disturbance and the dynamics of pattern. Ecol Monogr 51:145-178

Rossi RE, Mulla DJ, Journel AG, Franz EH (1992) Geostatistical tools for modeling and interpreting ecological spatial dependence. Ecol Monogr 62:277-314

Sokal RR, Oden NL (1978) Spatial autocorrelation in biology 1. Methodology. Biol J Linn Soc 10:199-228

Sokal RR, Rohlf FJ (1995) Biometry, 3rd edn. WH Freeman and Company, New York

Sousa WP (1985) Disturbance and patch dynamics on rocky intertidal shores. In: Pickett STA, White PS (eds) The ecology of natural disturbance and patch dynamics. Academic Press Inc, London, p 101-124

Southward AJ (1956) The population balance between limpets and seaweeds on wave beaten rocky shores. Annu Rep Mar Biol Stat Port Erin 68:20-29

Southward AJ (1964) Limpet grazing and the control of vegetation on rocky shores. In: Crisp DJ (ed) Grazing in marine and terrestral environments. Blackwell Scientific, Oxford, p $165-173$

Thomson JD, Weiblen $G$, Thomson BA, Alfaro $S$, Legendre $P$ (1996) Untangling multiple factors in spatial distributions: lilies, gophers and rocks. Ecology 77:1698-1715

Underwood AJ (1997) Experiments in ecology. Cambridge University Press, Cambridge

Underwood AJ, Chapman MG (1996) Scales of spatial patterns of distribution of intertidal invertebrates. Oecologia 107:212-224

Upton GJG, Fingleton B (1985) Spatial data analysis by example, Vol 1, Point pattern and quantitative data. John Wiley and Sons, Chichester

Vadas RL, Johnson S, Norton TA (1992) Recruitment and mortality of early post-settlement stages of benthic algae. Brit Phycol J 27:331-351

Submitted: June 2, 1997; Accepted: October 21, 1997

Proofs received from author(s): December 2, 1997 